\title{
PHOTOSYNTHESIS AND RESPIRATION \\ OF THE PHYTOPLANKTON \\ IN SANDUSKY BAY
}

\section{DISSERTATION}

Presented in Partial Fulfillment of the Requirements For the Degree Doctor of Philosophy in the Graduate school of the ohio State University

By

ARTHUR GEORGE MCQUTTTE, B.S.; M.S.

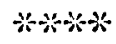

The Ohio State University 1954

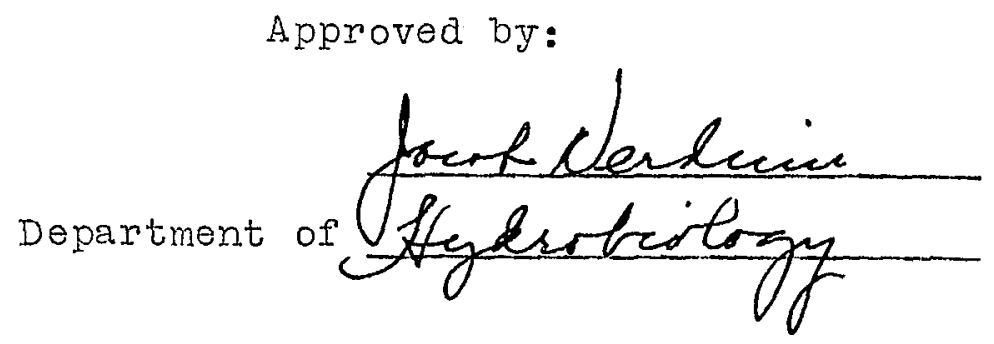


TABLE OF CONTENTS

$\begin{array}{lr}\text { INTRODUCT ION } & 2 \\ \text { METHODS } & 6 \\ \text { RESULTS } & 10 \\ \text { DISCUSS ION } & 32 \\ \text { SUMMARY } & 39 \\ \text { REFERENCES } & 42\end{array}$

1 


\section{INTRODUCTION}

The present paper concerns a study of photosynthesis and respiration of the phytoplankton in Sandusky Bay, conducted from February 2 to June 18, 1954. Sa ndusky Bay, a drowned embayment, has conditions of great turbidity that are peculiar to itself and in contrast to those of western Lake Erie. Because of the important role of photosynthesis in the energy relations of the aquatic environment, an intensive study of this process was considered desirable under these conditions.

Laboratory facilities were established at Winous Point, located at the point of a peninsula projecting into the upper Bay. At this position the Bay is approximately one mile in width and the water is essentially a mixture of the effluent of the tributaries with that of the embayment.

Sandusky Bay lies in ottawa, Sandusky and Erie Counties in northern ohio. It is the principal indentation of the southern shore line of western Lake wrie, Figure 1. The Bay is approximately 14 miles in leneth and has an average width of nearly 4 miles. The lone axis lies nearIy in an east-west direction and consequently is exposed to the maximum influence of the prevailing, winds. The shore line is characterized by great regularity, there being 0.788 mile of shore line per square mile of area (Nil- 
a

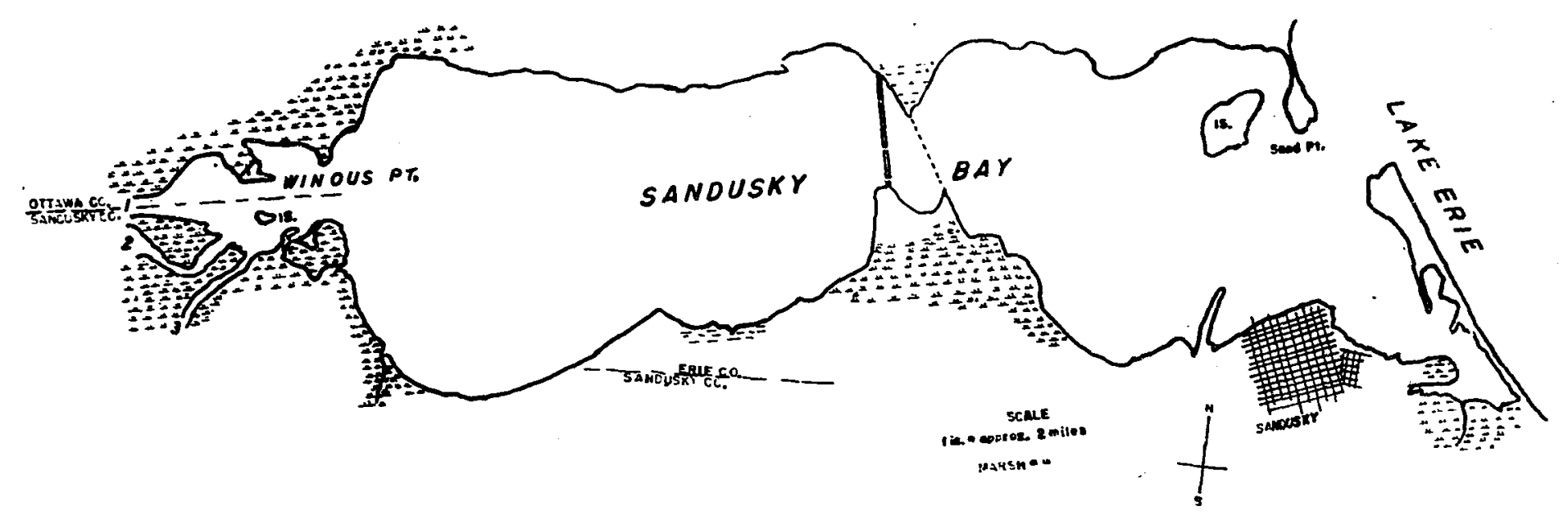

Pisure I

A map of Sandusky Bay modifiej Irom the U. S. Lake Survey hap (1949) by the Corps of Engineers oi the U. S. Army. The location of Winous Point is indicated by $(x)$. Tributaries flowing into the Bay are (I) Muddy Creek, (2) Sandusky River, and (3) South Creek. 
son, 1938).

The Bay is crossed midway by the Bay Bridge causeway which comprises a land-fill with openings for the passage of. water. The Bay is shallow, seven feet $(2.1 \mathrm{~m})$ being the maximum deptb shown by the topographical map of the U. S. Geological Survey (1901) and verified by Wilson (1938); 33\% of the basin has a depth between 6 and 7 feet. The upper portion of the Bay (west of the bridre), with which this study is concerned, has an area of 27.97 square miles, a meximum length of 7.7 miles and an average width of 3.7 miles (Wilson, 1933). The averase depth of water in the vicinity of Winous Point is approximately one meter; however, due to frequent strong seiches the depth may vary from one bali meter to two meters.

A basin as long and shallow as Sandusky Eay, lying in the direction of the prevailing winds, and with low, regular shore lines, is subject to considerable disturbance of the water. These aisturbances bring bottom sedinents into suspension and attack the clay banks along both the north and south shores. During a "blow" the water becomes very turbid. rost of the shore line has clay banks, a small portion has supericial pravel or stone rip-rap cover (Ianglois, 1054). Rapio erosion of the clay banks along the north and soluth sizores is evidence of the effectiveness of the attack. There are only a few small patches of 
rooted vegetation remaining in the Bay.

Three converging tributaries discharge their effluents into the upper end of the Bay. The Sanasky River is the principal tributary, the others are mady creek and South creek. The drainage area of the sandusky River is 1421 square miles (Ianglois, 1954), and lies in fertile, agricultural soils which formerly comprised the extinct glacial Lake raumee basin. The total discharge (secondfoot-days) of the Sandusky River for the period cotober 1050 to September 1051 was 507,624 and the total load of suspended sediment for the period was 260,024 tons. Iarge volumes of available nutrients, eroded from the arricultural soils, are carried into the Bay (Lake Brie pollution Survey, 1853).

Considerable marsh land surrounds the upper end of the Bay and this is the only portion of the shore line with any sienificant amount of rooted aguatic veretation. Srall bays and open pockets in these marshes provide excellent cultural pounds for plankton which are carried into the Bay and eventually reach the waters of Iake Irie. The author acknowledges the assistance of the followine people: Dr. Jacob Verduin, who sumested the problem and served as adviser; Dr. T. H. Ianglois, Director of the Franz Theodore Stone Institute of Hydrobiology, who provided equipment and counsel; Mr. John lij. Anclerson, 
lranager of the Winous Foint Shooting Club, who provided laboratory facilities; Messrs. Christian Christianson and Jorman Rounds, who provided information regarding the Bay and aided with transportation on the Bay; Dr. Edward C. Kinney, Jr., who photographed the figures; Mr. Walter C. Knoblaugh, who helped to construct the under-water photometer; and hrs. Inoblaug, who typed the manuscript.

$$
\text { MTEODS }
$$

The method used for determination of rates of plotosynthesis and respiration was described by Verduin (1951). In brief, it consists of measuring the change in bH of water samples unon removal of carbon dioxide by photosynthesis or upon evolution trrough respiration. The equiljorium equations published by ríore (1S39) and the nomographs by Dye (1944) provice tio tbeoretical basis for the determinations of carbon dioxide exchenge. Verauin has observed (unpublistud) that Dye's nomographs do not give a true picture of total carbon dioxide change in waters containing substances of considerable buffering effect. Thererore, an actual buffer-curve was constructed by stepwise titration of a liter of the water sample with naof of known normality; the relationship so established was used in computing $\mathrm{CO}_{2}$ change.

A pail of water of approximately ten liters, removed from the surface of the Bay at 8 am, provided the water to 
fill the series of test bottles and also the sample for the estimation of the phytoplankton population. The temperature of the water and the initial pef were immediately recorded.

The capacjty of the test bottles was $140 \mathrm{ml}$, glass stoppered, and they were filled by being submerged and stoppered under water in order to eliminate air bubbles. Seven clear and two blackened botties were usea. After filling, each bottle was attached in a horizontal position to a cord and suspended in the Bay with the botties at $0.1 \mathrm{~m}$ intervals in a vertical series at such a place that they received unobstructed exposure to the lisht. The first bottle was at the surface of the water and the two black botties were at the bottom of the series. The support, to which the cord was fastened, was anchored to the concrete pier, except on those occasions when seiches would flood tire pier. At such times the botties were suspended from a bridge.

The experimental run was for six hours $(9$ am to $3 \mathrm{pm})$. The bottles were then removed from the Bay, submereed in a pail of Eay water to prevent change in temperature, and carried to the laboratory where the oH (average of three determinations) was recorded for each bottle. The $\mathrm{pH}$ and the temperature of the open water were a lso taken at the end of the experimental run so that 
apparent photosynthesis in the open water could be compared with that of the closed system in the test bottles.

Using standard water-sampling bottles of $300 \mathrm{ml}$., samples of water were taken at 8 am with a modified Fale's water sampler (Welch, 1948) for the determination of dissolved oxygen, free carbon dioxide, phenolphthale in and methyl orange alkalinities (Standard liethods for the Examination of Vater and Sewage.- Sth wd.).

General weather conditions, including temperature, wind direction and velocity, precipitation and licht conditions were observed and recorded.

Light intonsity at the surface of the water and at $0.1 \mathrm{~m}$ intervals were measured at $10 \mathrm{am}$ and at $2 \mathrm{pm}$ by means of a Weston photronic cell, Model $856 \mathrm{RR}$, enclosed in a water-ticht case which was lowered into the water by a water-proof electric cord. The electric impulse was recorded in microameres from readins of an ammeter. The lireht intersities were plotted on semi-log paper and the decimal reduction distaruce (DRD), or depth to which $10 \%$ of the surface licht penetrates, was recorded for each experimental run.

About miciway throun the period of investigation, it became apparent that a simultaneous experimental run for the measurement of oxygen exchance should be instituted as a check on the carbon dioxide data. Consequent ly, a series 
of three water-sampling bottles, one of which was lightproof, was fjlled with the sample water and suspended in the Bay for a six-hour experimental run. One bottle was held at the surface, another at $0.2 \mathrm{~m}$, and the blackened bottle was lowered to the bottom. All dissolved oxyeen analyses were made by the Winkler method (Standard Hethods for the Examination of Water and Sewage.- 8th Ed.). Considerable difficulty was encountered at first in correctly determinine the amount of dissolved oxyen. Later, it was discovered that the formula for the titration reagent, sodium thiosulfate as described by Welch (1948) "6.205 $\mathrm{Na}_{2} \mathrm{~S}_{2} \mathrm{O}_{3}$ " was in error, when compared to the formula for sodium thiosulfate prescribed by Standard Methods for the Examination of Water and sewae.- eth Ed., as follows: "6.205 E. of $\mathrm{Na}_{2} \mathrm{~S}_{2} \mathrm{O}_{3} \cdot 5 \mathrm{H}_{2} \mathrm{O}$. The aissolved oxygen complatations were 50\% too low until correction was made for this reagent.

At first, estimation of the phytoplankton population was attempted by filtering a measured liter of sample water throlarh a No. 25 silk bolting cloth ijter. The filter was washed with $10 \mathrm{ml}$. of distilled water and one milliliter of the concentrate was placed in a sedgwich-Rafter cell. Ten fields were counted by using a whipple ocular countine disc, averased, and 3 -dimensional measurements made of the abundant species (Welch, 1948). It was soon 
apparent that this method was not accounting for a significant portion of the population, as it was observed that the most abundant organjsms were unicells and too small to be retained by the filter. These were so abundant that a direct count could be made from one milliliter of water in the Sedgwick-Rafter cell. Consequently, the phytoplankton population was estimated volumetrically ( $\mu^{3}$ per liter) by adding the count of colonial and filamentous forms obtained from the concentrated sample to that of the unicells obtained by the direct method. All zooplankters were ignored in this study.

The total slapensoids and ash-free dry weight of organic matter per liter were determined gravimetrically by centrifuging a liter of the sample water in a Foerst centrifure, aryine the concentrate in a constant-temperature electric oven at $60^{\circ} \mathrm{C}$, weighing, igniting and reweighing (Welch, 1948). For these weighings a chemical balance with a sensitivity of $0.1 \mathrm{mg}$. was used. To conrect for organic and inorenic mater in solution in the Bay water, a blank was run usine the same amount of centrifuged water as was used to transier the concentrate from centrifuge to crucible.

\section{RESUITS}

The dissolved oxygen in the Bay water ranged from a maximum of 14.25 ppm in February at $0.0^{\circ} \mathrm{C}$ to a minimum of 
$5.92 \mathrm{ppm}$ in June at $25.0^{\circ} \mathrm{C}$, and averased $10.3 \mathrm{ppm}$, or $88.6 \%$ of saturation.

The initial pH varied from day to day, the minimum of 7.74 was recorded in April and maximum of 9.06 in early March, with an averae of 8.25 for the period. Free carbon dioxide was present when the pH dropped below 8.3 and varied from 0.0 to 11.0 ppm. During the period of Farch 26 through April 29, the pH was consistently low and was associated with the presence of free carbon dioxide. Aside from this prolonged period, free carbon dioxide was intermittently present throughout the entire period.

The alkalinity of the sandusky Bay water is due almost entirely to bicarbonates. The methyl orange alkalinity varied from $79 \mathrm{ppm}$ to 210 ppm and averaged $132 \mathrm{ppm}$. The maximum was recorded on february 5 , after wich the total alkalinity showed a steady decline until mid-April, then an increase to a relatively consistent averase to the end of the stuay. Only once dia the total alkalinity drop below 100 ppm, April 19, when the DRD was $0.11 \mathrm{~m}$, sligesting an important injection of turbid water.

Normal carbonate values were imregular from week to week and ranged from 0.0 to $15.0 \mathrm{ppm}$. There may be experimental error involved here due to the difficulty of judging the end-point in the color change. Invariably there was no measurable phenolphthalein carbonate below 
pH 8.3. Normal carbonates were consistently absent from Warch 26 through May 5, then present until lray 20 , after which they were intermittently prosent.

The waters of Sandusky Bay are characterized by high turbidity. This conaition is primarily due to (1) wind and resulting wave action which erodes the clay shore lines and causes a resuspension of bottom sediments in the shallow basin, and (2) the silt and detritus-laden discharge of the tributaries. Throughout the period of the study, the decimal reduction distance varied from $0.03 \mathrm{~m}$ to $0.92 \mathrm{~m}$ and averaged $0.36 \mathrm{~m}$.

The temperature of the water was uniform from surface to bottom. There was no thermal stratification. Water temperatures approximated that of the atmosphere within a few derrees.

Gravimetric determinations of total suspensoids and their ash-freo dry weight began the first veek of riay and continued to the end of the study. The data obtained on Nay 3 followed a period of precipitation and bigh winds, resulting in extreme turbidity. The total oven-dry suspensoids for this day were $1128 \mathrm{me}$. per liter and the ashfree dry weimt of organic matter was $300 \mathrm{mg}$ - per liter. This day was exceptional auring this part of the stuay, and it was assumed that the major portion of the organic matter consisted of non-livine detritus, hence these 
weights are not included in the averages during this seven weeks. The oven-dry suspensoids varied from 30.0 to 233.8 me per liter; the net ash-free ary weights ranged from 6.0 to $27.8 \mathrm{mg}$ per liter with an average of $11.78 \mathrm{mg}$. In figure 2 , the rates of total photosynthesis (micromoles $\mathrm{CO}_{2}$ absorbed per hour per $10^{10} \mu^{3}$ ) on five dirferent days are plotted against light intensity. Comparins the data points of the aifferent days, there is a rather wide scatter, the hiphest curve showing maxima about 2.5 times the values of the lowest curve. The data for each day present a fairly smooth curve. All the curves show some depree of inhibition at the surface, regardiess of the surface lisht intersity. In each case the maximum rate appears in the second bottle of the series $0.1 \mathrm{~m}$ below the suriace. The rates on any single day cannot be considered a represontative sample, but the mean of severa d days represents a more reliable estimate of average performance.

In figure 3, the photosynthetic rates, based on micromoles $\mathrm{CO}_{2}$ absorbed per me ash-iree dry weight of suspensoids for the same five days as in ficure 2 , are plotted against light. In this eraon, similar curves appear but the scatter is reduced considerably. The maxima of the hirhest curve beine only 1.7 times those of the lowest curve. These data suggest that ash-free dry weight of 


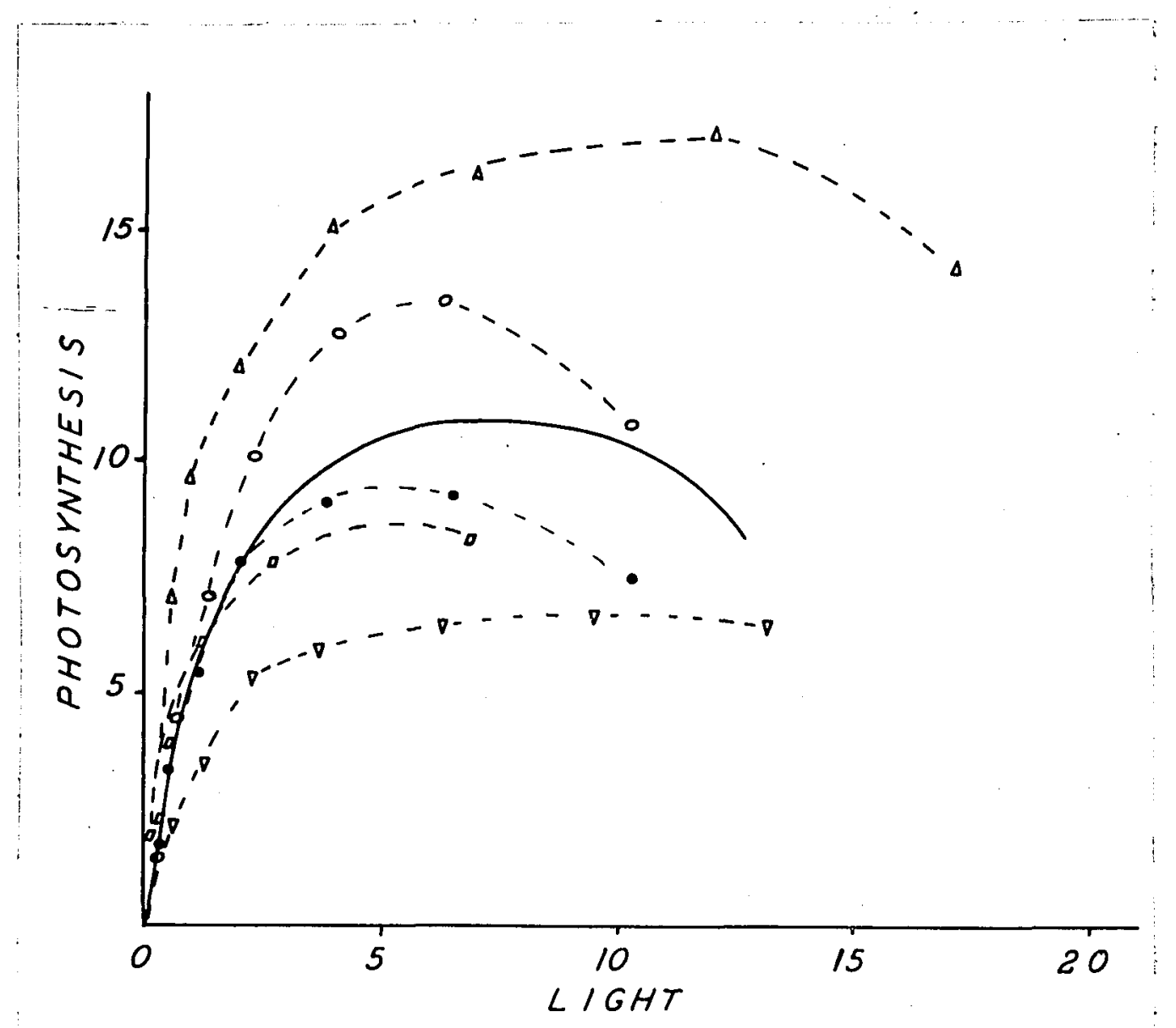

Figure 2

rotal photosynthesis ( $\mu$ moles $\mathrm{CO}_{2}$ absorbed /hour $/ 10^{10} \mu^{3}$ ) graphed agajinst lignt ( $\mu$ amps Weston photronic celI $\left.\times 10^{-3}\right)$. The broken lines represent rates on five different days. The solid line indicates the averape of the five days. 


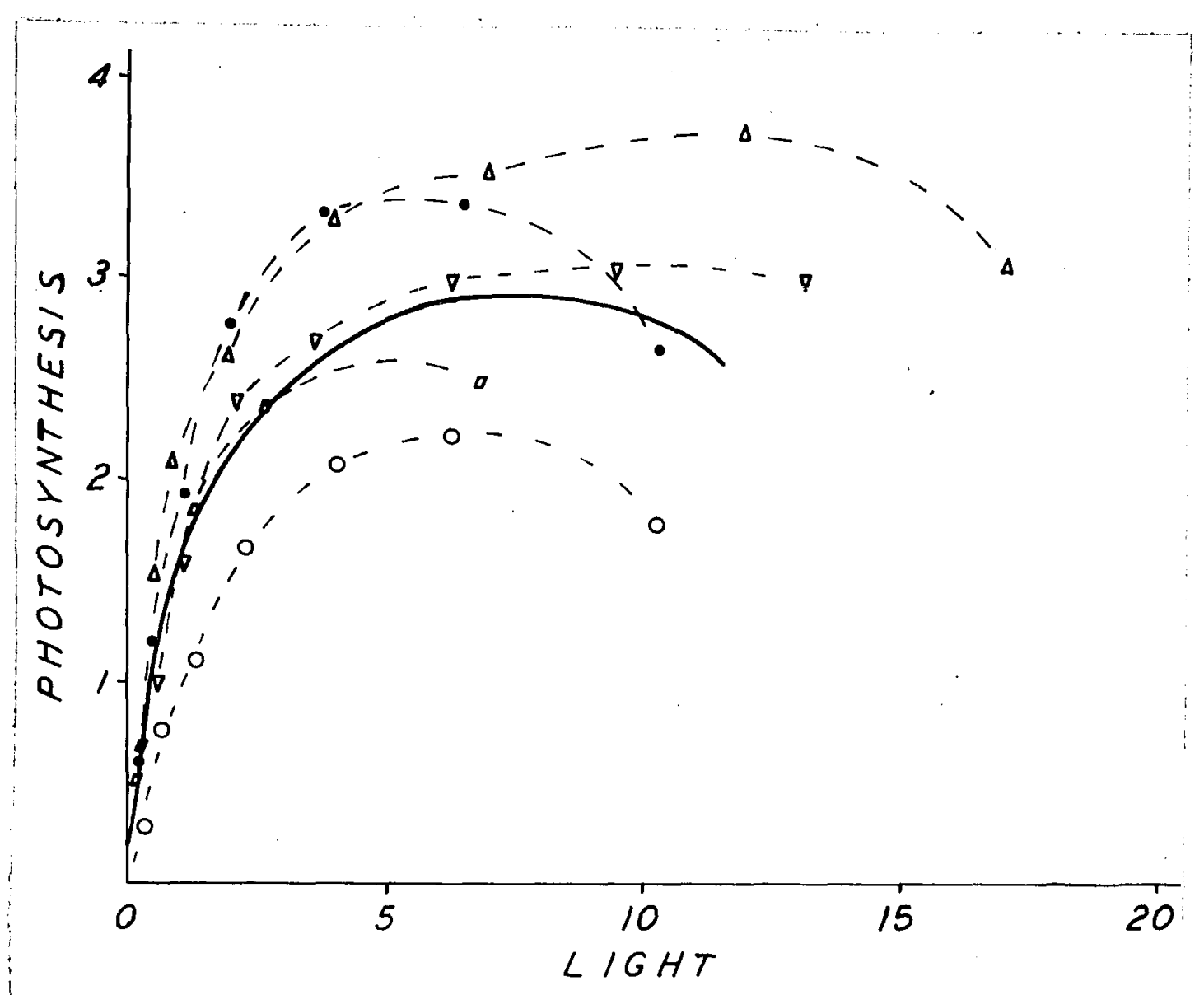

\section{Figure 3}

Total photosynthesis ( $\mu$ moles $\mathrm{CO}_{2}$ absorbed/hour /mg ash-free dry weight) graphed against light ( $\mu$ amps Weston photronic cell $\left.\times 10^{-3}\right)$. The broken lines represent rates on five different days. The soljd line indicates the average of the five days. 
suspensoits was a better index of photosynthetic capacity than was the volumetric standing crop of phytoplankton for these five samples.

Total photosynthesis, as based on carbon dioxide consumption, is prahed asainst temperature in fjoure 4. Means are indicated by open circles. The average photosynthetic rate Ior the temperature range $0.0^{\circ} \mathrm{C}$ to $10.0^{\circ} \mathrm{C}$ was $0.22 \mu$ moles $\mathrm{CO}_{2}$ removed per hour per $1010 \mathrm{p}^{3}$. The averare rate for the temperature rance $15.00 \mathrm{C}$ to $25.00^{\circ} \mathrm{C}$ was 14.01 1 moles per hour per $1010 \mu 3$ or roughly twice the rate at the lower temperatures. Both of these rates are associated with lare standing crops; however, they are related to different commities, the former bejng nearly a pure stand of Cyclotella and the latter predominately Melosira. The photosynthetic rates for the temperature ranse $5.00 \mathrm{C}$ to $15.00^{\circ} \mathrm{C}$ averare much hisher than the rates on either side of this interval and apparently are not attributable to temperature. They were observed auring a period of extremely low populations and low decimal reduction aistances.

Figures 5 and 6 show photosyntiesis rates per $10^{10} \mu^{3}$ per hour raphed against standing crop of phytoplankton per liter. In figure 5 the rates are determined from $\mathrm{CO}_{2}$ change, and in figure 6 the rates are based on $\mathrm{O}_{2}$ change. The scatter diagrams in these fijgures are essentialy 


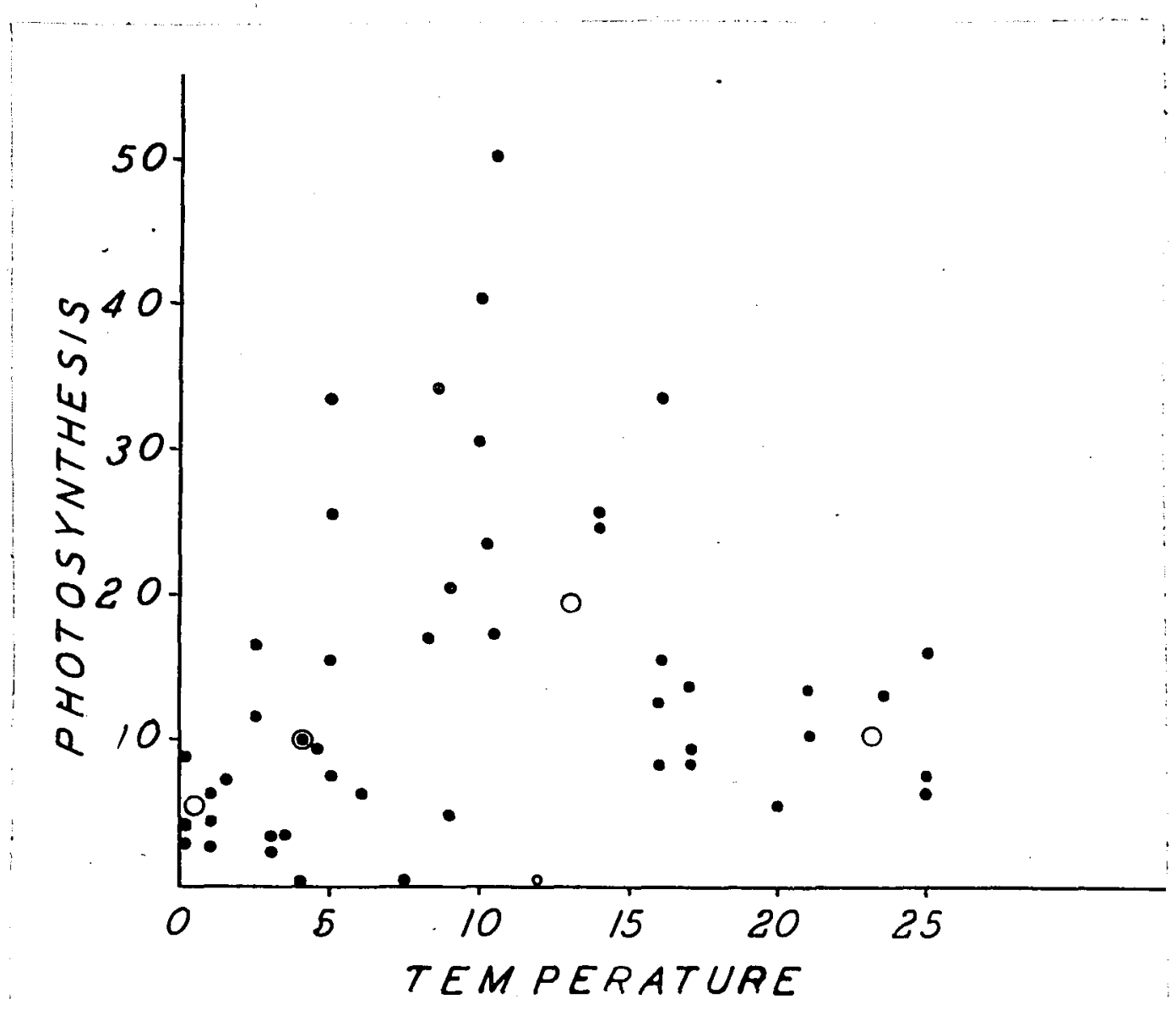

\section{Pigure 4}

Relationship of $\mathrm{CO}_{2}$ removal ( $\mu$ moles/hour $110^{10} \mu^{3}$ ) at optima I light intensity to temperature ${ }^{O} \mathrm{C}$. Means are indicated by open circles. 


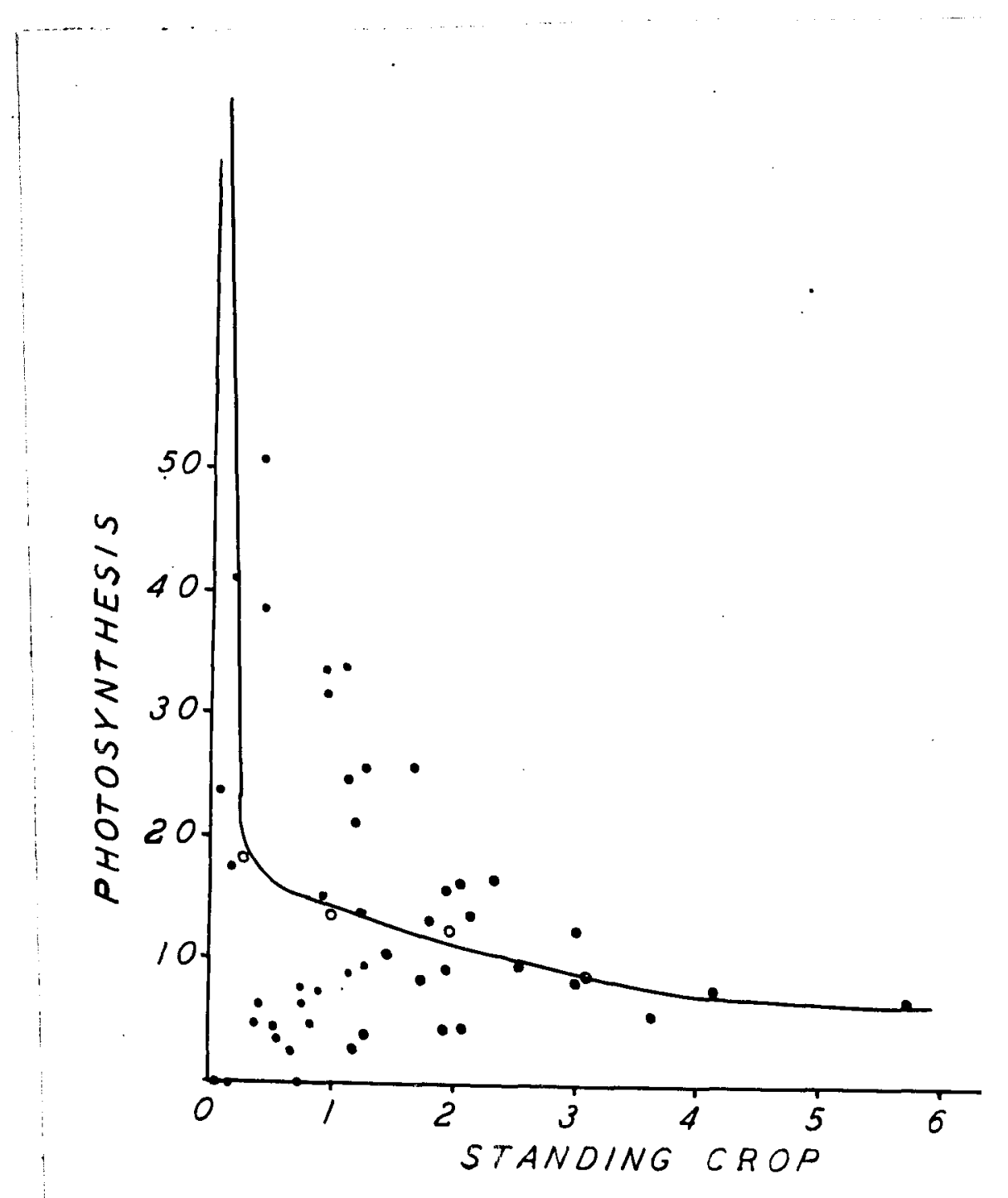

목ore 5

Total photosynthesis ( $\mu$ moles $\mathrm{CO}_{2}$ absorbed/hour $/ 10^{10} \mu^{3}$ ) at optimal licht plotted against the volume of phytoplanicton naturaliy present in one liter of water ( $3 /$ Iiter $\left.x 10^{-10}\right)$. 


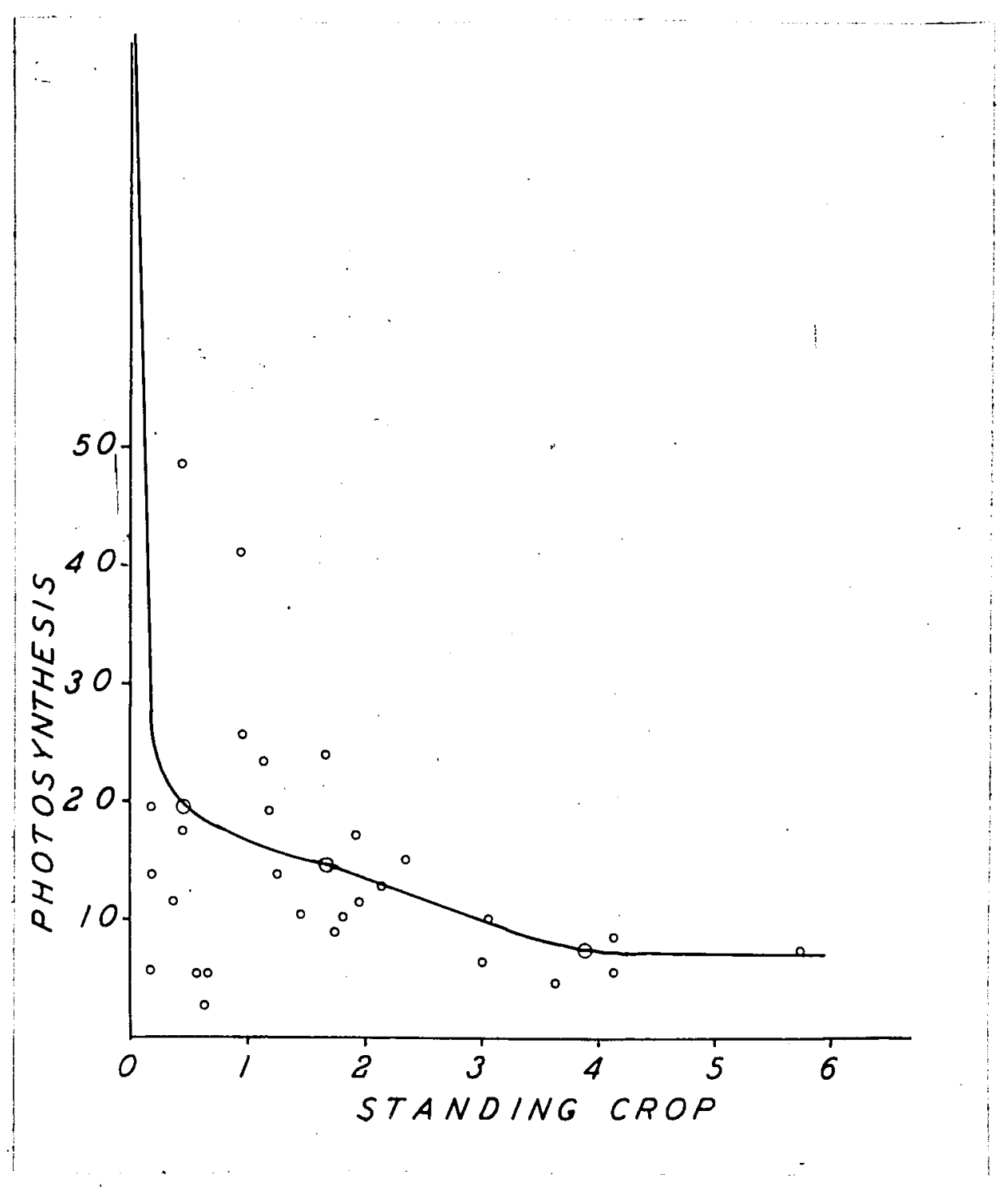

Pigure 6

Total nhotosynthesis ( $\mu$ moles on avolved/hour $/ 10^{10} \mu^{3}$ ) at optimal licht graphed against the volume of phytoplankton naturally present in a liter of water ( $\mu^{3} /$ liter/ $x$ 10-10). 
alike, indicating that these two separate methods of de-

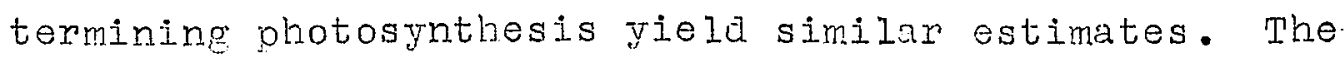
average values (open circles) were used in drawing curves, and the high values mentioned below, which go off scale, justify the upward extensions of the curves. The means show a gradual downward slope over most of the graph but a sharp bend and a rapidy ascending rate appoars at the poplatation level of about $0.3 \times 10^{10} \pi^{3}$. The data indicate an inverse ratio between photosynthesis rates and the standing crop. The rates approached phenomenal values during the perinds of extremely low populations. The following sequence of rates were obtainea on a sequence of days from April 20 to Iray 3: 323.0, 632.0, 356.0,904.0, 711.6 micromoles $\mathrm{CO}_{2}$ removed per $10^{10} \mathrm{p}^{3}$ per hour. The averare photosynthetic rate for the entire period, inclusjve of the above hioh rates, was 74.0 micromoles per $10^{10} \mu^{3}$ per hour. sxcluding the period of high rates, the average rate was 15 micromoles $C_{2}$ renoved per $1010 \mu^{3}$ per hour. The ratio of $\mathrm{CO}_{2}$ consumed to $\mathrm{O}_{2}$ evolved $\left(\mathrm{CO}_{2} / \mathrm{O}_{2}\right)$ was 0.87 .

Fhotosynthesis rates were also computed per me. of asb-free ary weight of suspensoids. The rates so expressed varied from 1.05 to $3.45^{\prime}$ micromoles $\mathrm{CO}_{2}$ absorbed per hour, and averaged 2.4. On the basis of orygen evoIution, the rates ranged from 0.49 to 3.33 micromoles $0_{2}$ 
per hour, and averaged 2.3. The photosynthetic quotient $\left(\mathrm{CO}_{2} / \mathrm{O}_{2}\right)$ was 1.04 .

In figure 7 , total photosynthesis ( $\mu$ moles $\mathrm{CO}_{2} /$ hour/ liter of water) is plotted against ash-free dry weight of suspensoils. These data were obtained during the period May 5 to June 18. The photosynthetic rates in experimental bottles ranged from 14 to 42 micromoles per hour per liter, with an average of 26. A line drawn through the means of the scatter-djapram indicates that the relationship appears linear; a correlation coefficient of 0.604 was obtained, and this is statistically significant at the $5 \%$ level. Correlation of $\mathrm{CO}_{2}$ consumption with standing crop was 0.388 ; of $\mathrm{O}_{2}$ evolution with ash-free dry weisht was 0.413 ; of $\mathrm{O}_{2}$ evolution with standing crop was 0.457 . The broken line shows the influence of one low reading taken subsequent to a storm, when total suspensoids were unusually hiph.

The rates of apparent pliotosynthesis in tie open water ior the period indicated above were calculated from the injtial pH and from the pe taken six hours later. This varied from a -5 to a +38 micronoles $\mathrm{CO}_{2}$ per hour per liter and averaged 12. For the entije period, February to June, the averase total photosynthesis at optimal Iight in the experimentel bottles was 17 micromoles $\mathrm{CO}_{2}$ consumed per hour per liter, and the average apparent 


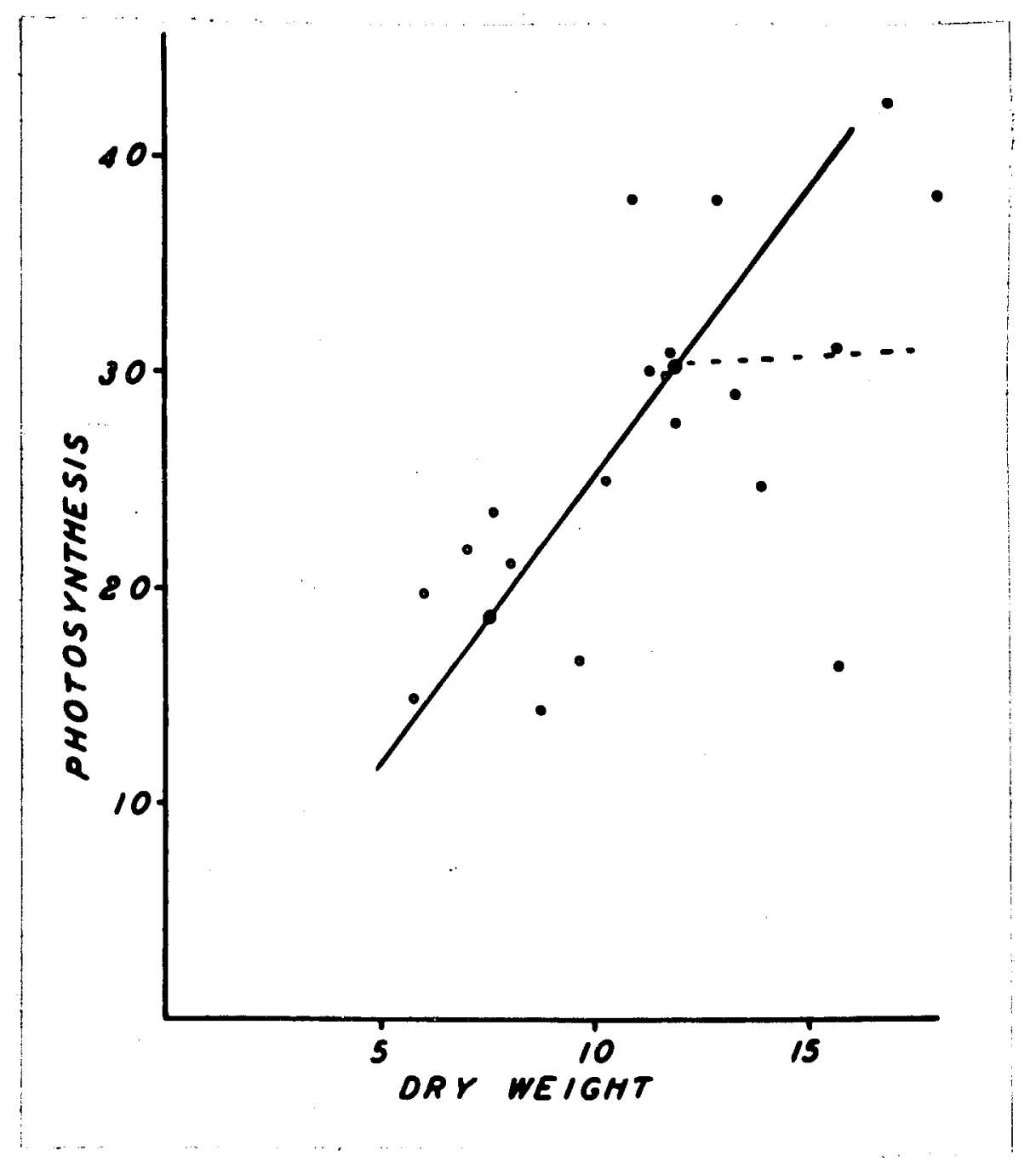

Pigure 7

Total photosynthesis ( $\mu$ moles $\mathrm{CO}_{2}$ absorbed /hour /iter) at optimal licht sraphed against ash-free dry weight of suspensoids in water (mg. per liter). 
photosynthesis was 13 . These data indicate close agreement between changes in the open water and changes in the experimental bottles, with apparent photosynthesis accounting for about three-fourths of total photosynthesis:

The euphotic zone, or depth to wich $1.0 \%$ of the surface limht penetrates, comprised approxirately $70 \%$ of the water mass, on the averace. For the pariod of May 5 to June 18, the averae photostrnthesis rate within the euphotic zone was 12 micronoles $\mathrm{CO}_{2}$ per hour per $10^{10} \mathrm{j}^{3}$ and 2 micromoles per me. ash-free ary weicht. The averace for the total water mass was 5.9 micromoles $\mathrm{CO}_{2}$ per hour per $10^{10} \mu^{3}$ and 0.9 micromoles per mg. ash-free ary weight.

Fizures 2 and $\theta$ show respiration rates per $10^{10} \mu^{3}$ graphed against standing crop. In figure 8 the rates determined from $\mathrm{CO}_{2}$ change are portrayed; in fizure 9 the rates represent $O_{2}$ chanres. Again, the average values (open circles) were used in drawing the curves, and the high values go off scale, justifyine the upward extension of the curves. A comparison of these ficures shows a much laroer scatter in the $\mathrm{CO}_{2}$ data than in the $\mathrm{O}_{2}$ data. The shape of the curve in both graph is similar and contains the same sharp increase at low populations that was observed in the photosynthesis clata, but the level of the $\mathrm{CO}_{2}$-based curve lies distinct $y$ above 


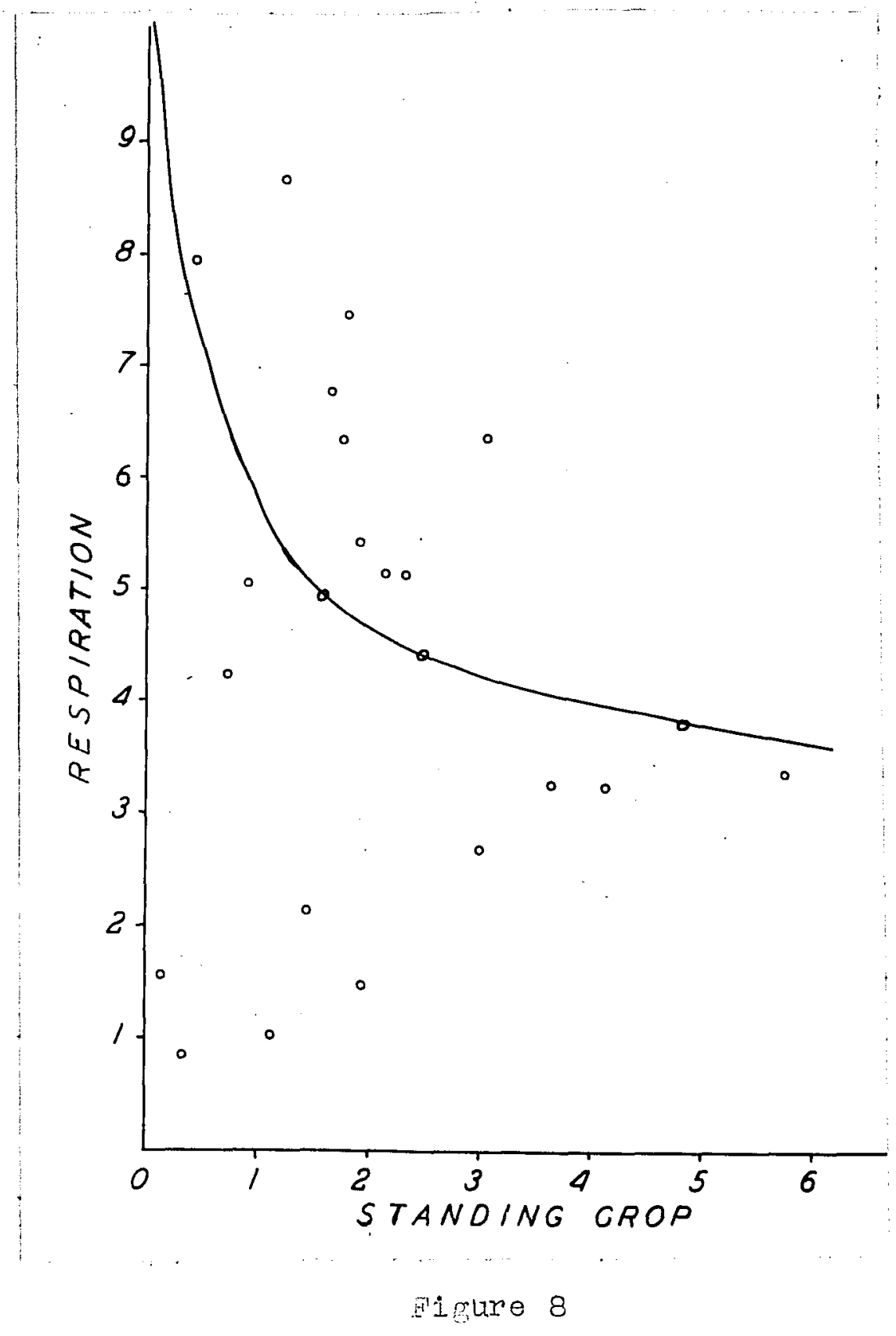

Respiration ( $\mu$ moles $\mathrm{CO}_{2}$ evolved /hour $110^{10} \beta^{3}$ graphed against phytoplankton popula tion $\left(\mu^{3} / 1\right.$ iter $\left.\times 10-10\right)$. 


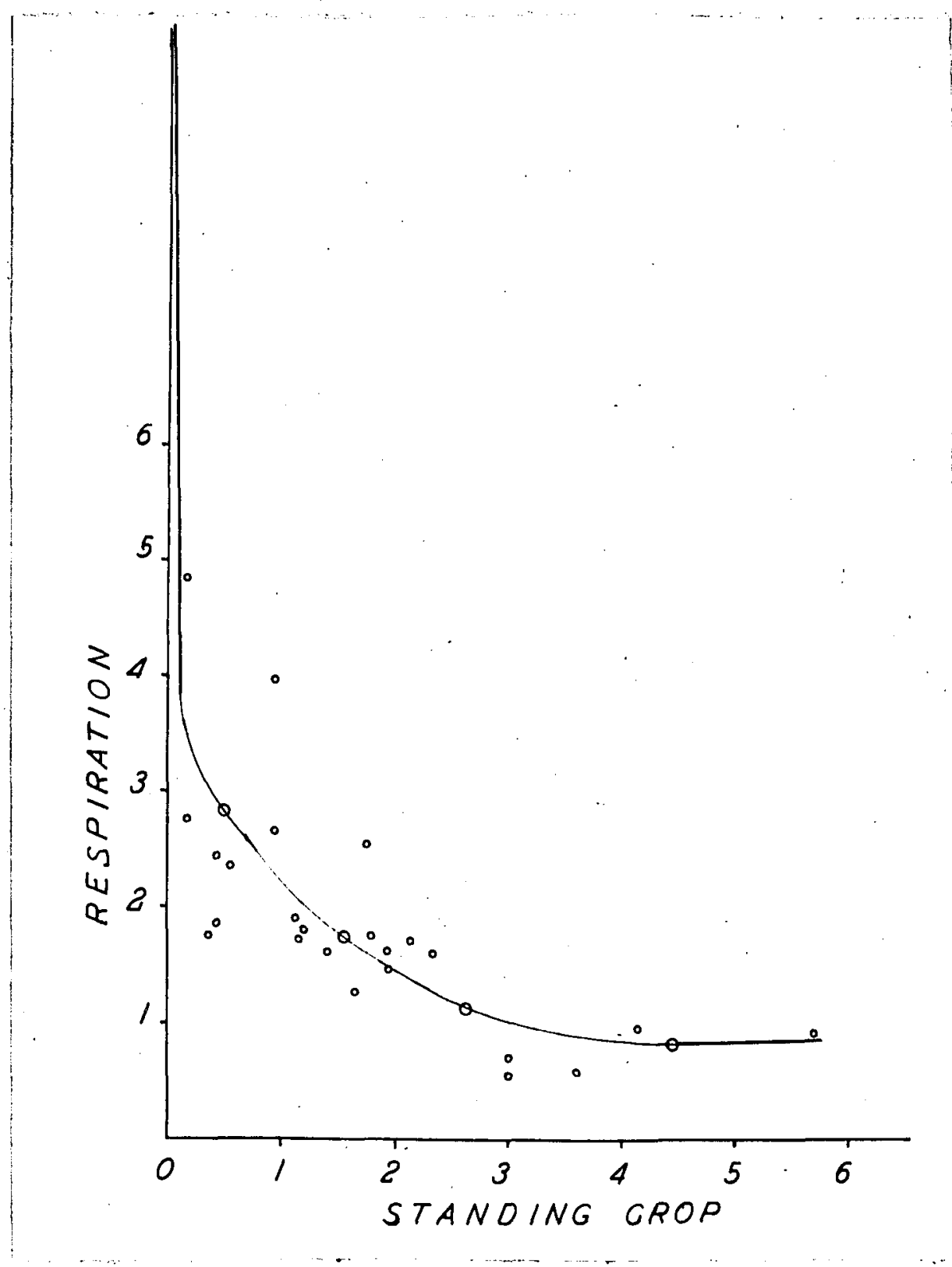

Figure 9

Respiration ( $\mu$ moles $o_{2}$ absorbed /hour $/ 10^{10} \mu^{3}$ ) graphed a gainst phytoplarkton population $\left(\mu^{3} /\right.$ iter $\left.\times 10^{-10}\right)$. 
that of the $\mathrm{O}_{2}$-based curve, indicating that respiration rates based on $\mathrm{CO}_{2}$ changes are several times higher than those based on $\mathrm{O}_{2}$ change. The average $\mathrm{CO}_{2}$ evolution was $4.72 \mu \mathrm{moles} / \mathrm{hr} / 1010 \mu^{3} ; 0_{2}$ consumption was $1.7 \mu \mathrm{moles} / \mathrm{hr} /$ $10^{10} \mu^{3}$, giving a respiration quotient $\left(\mathrm{CO}_{2} / \mathrm{O}_{2}\right)$ of 2.7 . When related to ash-free dry weight of suspensoids, the average $\mathrm{CO}_{2}$ evolution was $0.887 \mu$ moles/hr/mg; the $\mathrm{O}_{2}$ consumption was $0.267 \mu$ moles $/ \mathrm{hr} / \mathrm{mg}$, and showed a respiratory quotient of 3.3

In figure 10 , respination rates relating to oxygen consumption per hour per $1010 \mu^{3}$ are plotted against temperature. A line drawn throurh the means indicate that the rates of oxygen consumption decrease with increasing temperature. This is somewhat surprising because temperature increases are usually associated with increased metabolic activity.

The time distribution of the standine crop is portrayed in figure 11. The study began with the standing crop receding from the crest of a pulse, followed by a steady decline to very low levels in April, then a rather rapid rise to a maximum in mid-June. The configurations of the population and DRD curves are similar and suggest that the standing crop is sirnificant $y$ influenced by lisht supply

Figure 11 also shows the decimal reduction distances against time. This curve reflects the extent and changes 


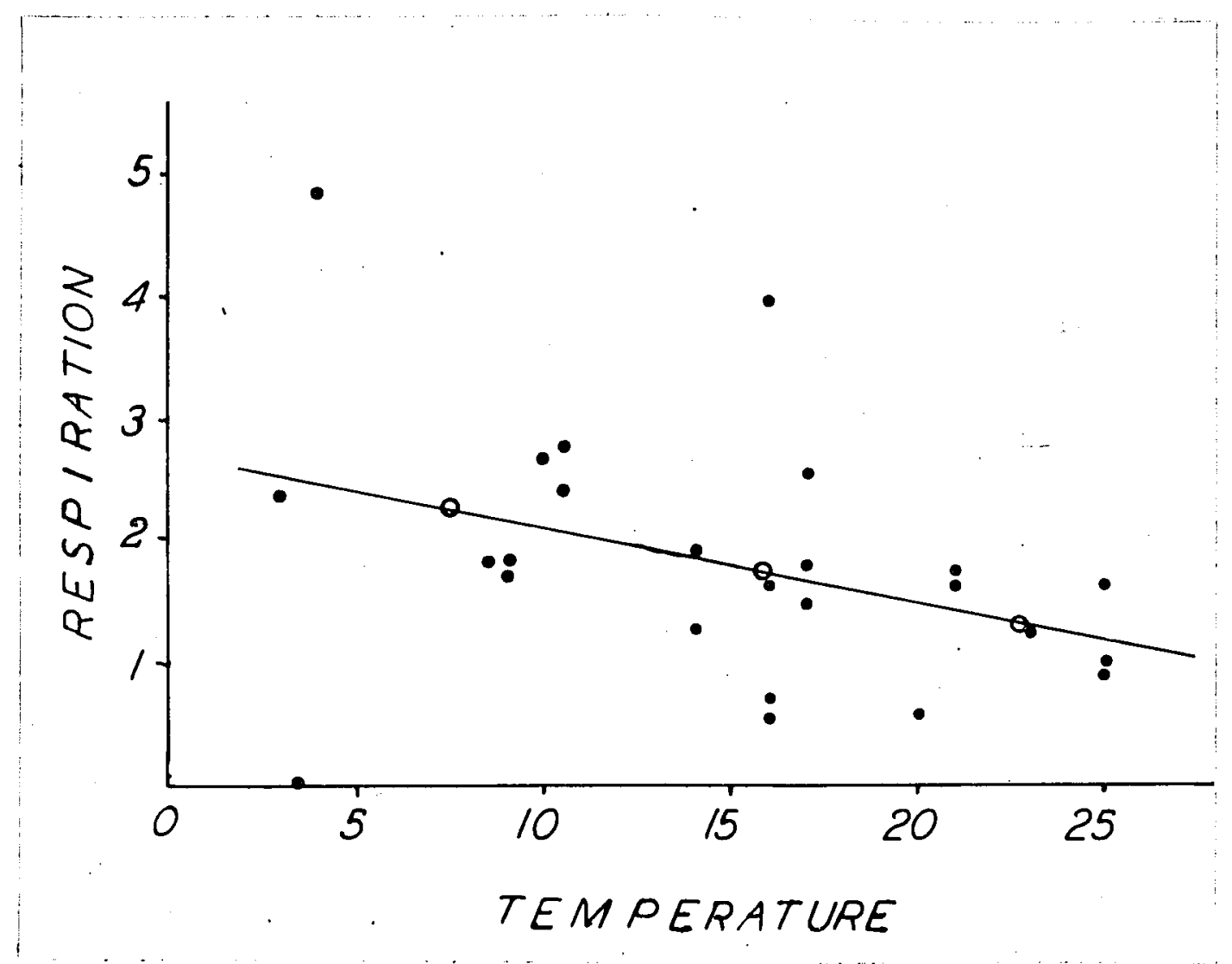

Pigure 10

Respiration ( $\mu$ moles on absorbed/hour/10 $10, \mu^{3}$ ) graphed agajnst temperature ${ }^{\circ} \mathrm{C}$. 


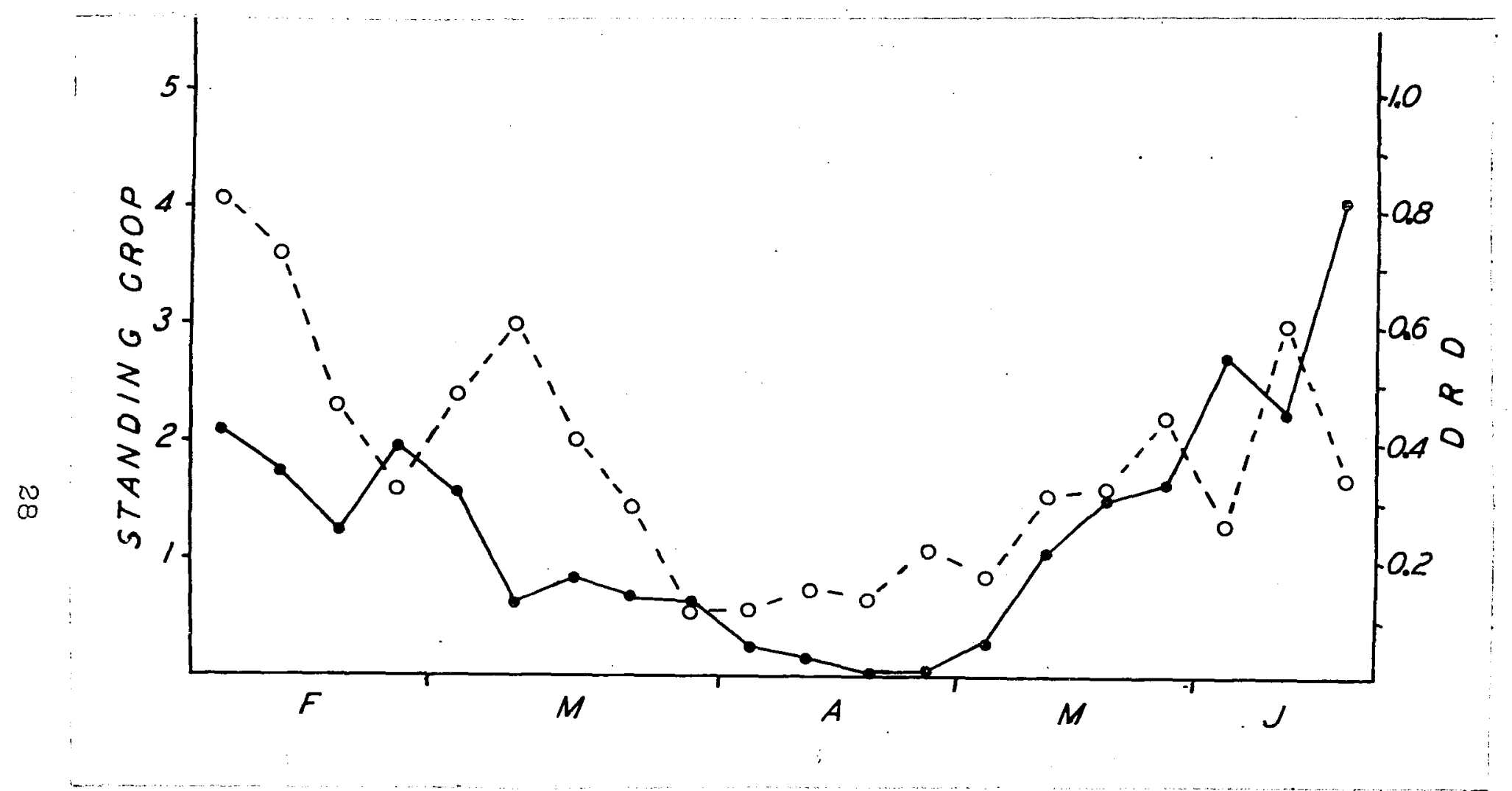

Figure 11

Comparison of phytoplankton populations ( $\mu^{3} /$ liter/x $\left.10^{-10}\right)$ and decimal reduction distance (DPD) in meters. Bach point on the graph represents the average of three determinations made during a week. The standing crop is indicated by the solid line and licht penetration by the broken line. 
in turbidity. Light penetration was at a maximum in February; a sharp decline was followed by a moderate rise in early march. Both of these crests were associated with an ice shoet and the declines were related to the disappearance of the ice, exposing the water to wind influence. Maximum turbidity and the minimum of light penetration occurred in April, caused by strong winds, precipitation and the resulting turbid effluent of the tributaries. Week to week fluctuations prevailed through may into June but with general lessening of turbidity accompanied by increasing light penetration.

The lipht absorption coefficient was calculated by the application of the Iambert-Beer's Law to the data obtained, beginning with the first week of liay. This varied from 0.07 to 0.15 and averared 0.12 for the period. The average value of this coefficient was very close to the average reported for Lake Erie (Verduin 1054), a Ithough the concentration of suspensoids is 10 times greater in Sanousky Bay than in western Iake irie.

The aistribution of phytoplankton populations in relation to decimal reduction distances is portrayed in ifgure 12. Fopalation means are plotted for each $0.1 \mathrm{~m}$ interval. This graph reveals a positive correlation of the standing crop with light penetration between abscissa values of $0.0-0.4$, but beyond this point the correlation 


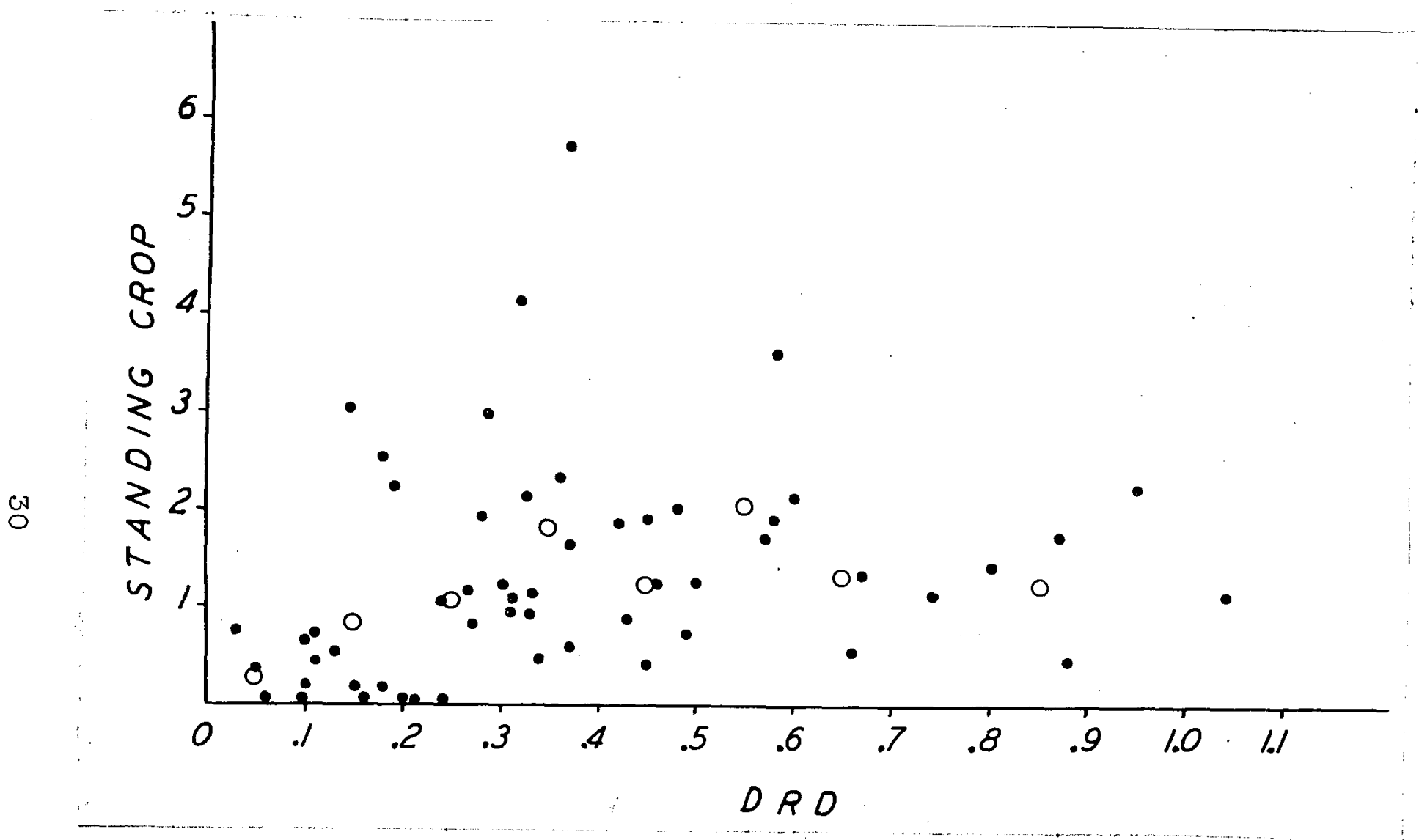

포일 12

Population of phytoplankton ( $3^{3} /$ liter $x$ 10-10) plotted against decimal reduction distance (DRD) for the period February 2 to June 18. Means for each $0.1 \mathrm{~m}$ are indicated by open circles. 
between light penetration and standing crop disappears. These data surgest that when DRD is reauced to less than one-third of the total depth, light becomes severely limiting and the size of the standing crop is largely determined by light penetration, but when the DRD is greater than one-third of the water column, factors other than licht supply exert a controlline influence on the size of the standing crop.

The average population for the temperature range 0.00 to $10.0^{\circ} \mathrm{C}$ was $1.1 \times 1.010 \mu 3$ and Cyclotella was the predominant genus. For the range of $15.00-25.0^{\circ} \mathrm{C}$, the average population was $2.4 \times 10^{10} \mu^{3}$ and Melosira was the major component.

At the start of this study on Pebruary 2 , the phytoplankton population apparently $\mathrm{h}$ : been or was at the crest of a pulse as the crop was $2.54 \times 1010 \mu^{3}$ per liter. Minety three percent of the crop consisted of Cyclotella, the largest component of which was identified by the author as Cyclotella michiganiana Skyortzow and this identification was confirmed in private communication by I. H. Tiffany. This genus was represented by 25 miliion cells per liter. The low crop in April, $0.007 \times 1010 \mu 3$ per liter, comprised a mixture of diatoms with 36,000 cells per liter. The June pulse attained a crest of $5.73 \times 10^{10} \mu^{3}$ per liter of which relosira varians $C$. A. 
Agardh and M. granulata (Ehrenberg) Ralfs . comprised 65\% of the population with 5,150,000 units per liter (100 u in length equals 1 unit).

The Bacillariophyceae comprised $96.7 \%$ of the February crop and $93.5 \%$ of the June crop. The phytoplankton. population, while abundant in number of individuals, showed a scarcity of genera. In addition to the two predominant genera mentioned, the following genera of diatoms were present in lesser fractions: Asterionella, Tabellaria, Fragellaria, Navicula, Gyrosigma, Pinnularia and Synedra.

The Chlorophycea were represented by Pediastrum, Actinastrum, Staurastrum, Coelastrum, Metrastrum, Scenedesmus, Jlothrix, Eldorina and Closterium. These represented less than. $1 \%$ of the plant volume present.

Oscillatoria, Inicrocystis and Aphanizomenon were the only genera of the Myxophyceae. Muglena, Phacus and Lepocinclis of the Euglenonhyceae were fairly common in early spring; Dinobryon of the Chrysophrceae was observed at the lower temperatures; and Peridinium was the only representative of the Dinophyceae.

\section{DISCUSSION}

In the respiration graphs, figures 8 and $\theta$, the discrepancy between carbon dioxide evolution and oxygen consumption poses a problem upon which the author can only speculate. Because of the photosynthetic rates for carbon 
dioxide consumption and oxygen production (figures 5 and 6) show a ratio near unity, one would expect a similar correlation of respiratory exchanges. The data indicate that a condition, or combination of factors, results in appreciable changes in $\mathrm{pH}$ either (1) through $\mathrm{CO}_{2}$ production in excess of $\mathrm{O}_{2}$ consumption, or (2) the formation of some other acid, or (3) a non-biological chemical reaction that produces a drop in pH during the six-hour enclosure in the black bottles. This phenomenon has not been recorded before. Throughout this period, average to excessive turbidity prevailed, affecting high concentrations of organic and inorganic suspensions from the bottom sediments. The situation sugrests release from the bottom muds of heterotrophic bacteria active in the fermentation of organic matter with the production of $\mathrm{CO}_{2}$, or some other acid (Henrici 1939). Little is known regarding the extent of bacterial populations in bottom muds or of the mannitude and quality of their metabolic products. The reports of Beaver (1942) and Weeks (1943) on the bacteria of Iake Erie do not appear to be pertinent to this study. The effect of the difference between $\mathrm{O}_{2}$ consumption and $\mathrm{CO}_{2}$ production upcn estimates of net photosynthes is (total photosynthesis minus respiration) is that the rates computed from $\mathrm{CO}_{2}$ data will be much smaller than rates computed from $\mathrm{O}_{2}$ data. For example, net photosynthesis 
for the entire water mas computed from $\mathrm{CO}_{2}$ data is -66 micromoles per liter per day and from $\mathrm{O}_{2}$ data $\$ 77$ micromoles per liter per day. More investigation is needed in this area of possible bacterial influence on rates. In figures 5 and 6 , the phenomenon of sharply increasing photosynthesis per $10^{10} p^{3}$ appears with low levels of standing crop and the entire curve shows an inverse relation to the phytoplankt on population. For several weeks during the summer of 1953 , studying samples taken from Put-in-Bay, I observed similar inverse ratios between photosynthetic rates and standing crop with rapidy rising rates associated with low populations. Experiments with Lake Irie water from which the phytoplankton had been removed by a To. 25 silk bolting cloth filter, showed average photosynthetic rates of $2.3 \mu$ moles $\mathrm{CO}_{2}$ removed per liter por hour. Obviously, these rates are attributable to a component of the phytoplankton not retained by the No. 25 bolting cloth filter. Fienrici (1039) suegests that "autotrophic bacteria are very probably of great importance in the metabolism of lakes. They f'all into two divisjons: the chemosynthetic species which obtain enerey from the oxidation of inorganic elements or compounàs (byarogen, sulphur, iron, ammonia, carbon monoxide) and the photosynthetic species. The latter, the red and peen sulphur bacteria, possess piments 
which, like chlorophyll, trap the energy of sunlight, and use it to transform carbon dioxide and bydrogen sulfide into organic matter" . van Niel (1935) in summarizing observations of photosynthesis in bacteria states "with regard to a concept of the mechanism of the photosynthetic conversion oi various $\mathrm{H}$-donors and $\mathrm{CO}_{2}$ into bacterial cells, nothing stands in the way of the hypothesis that fundamentally this conversion follows the same path as Freen plant photosynthesis".

It seems reasonable to suspect that the flora of the Bay contains a significant fraction of chemosynthetic and photosynthetic bacteria, the metabolic activities of which may explain both the inverse correlation between photosynthesis per unit plant volume and standing crop, and the him $\mathrm{CO}_{2} / \mathrm{O}_{2}$ respiratory ratio. Ihis problem needs considerable study before there can be a thorough understandins of phytoplankton metabolism.

The averare total photosynthetic rate for the entire water column, nay 5 to Jurie 18 was 12 micromoles $0_{2}$ evolved per liter per howr, or 144 micromoles evolved in 12 hours of deylitht. Whe average rate of respiration was $2 . e$ micromoles $\mathrm{O}_{2}$ consumed per liter per hour, or 67 micromoles consumed in 24: hours. Photosynthesis presents a net ain of 77 micromoles of $0_{2}$ per liter in 24 hours. 
Riley (1940), for Iinsley Fond, reported an average rate of $1.065 \mathrm{mg}$. $\mathrm{O}_{2}$ evolved per liter per weel for the entire water mass, which amounts to 4.75 micromoles per liter per day; and he reports $1.357 \mathrm{me}$. $\mathrm{O}_{2}$ consumed per liter per week, which amounts to 6.07 micromoles consumed per day. A net loss of 1.32 micromoles $0_{2}$ per liter per day is indicated.

Wright (1854) reported a photosynthetic rate of 0.39 $\mathrm{me} \cdot \mathrm{O}_{2}$ produced per liter per 48 hours in Atwood Lake, which amounts to 6.1 micromoles $\mathrm{O}_{2}$ per liter per day; and a respiration rate of $0.54 \mathrm{mg}$. $\mathrm{O}_{2}$ absorbed per liter per 48 hours, which amounts to 8.4 micromoles $\mathrm{O}_{2}$ consumed per day. This represents a net loss of 2.3 micromoles $\mathrm{O}_{2}$ per liter per day.

There is considerable difference in the period of exposure of test bottles in the above-mentioned experiments (Riley 7 days, Wright 2 days, present study 6 hours) and some of the differences appearing in the above comparisons may be due to that fact. But the shallow waters of Sandusky Fay, with hich phytoplankton crops (about 3 times as high as in Linsley pond) and high values of suspensoid ash-free ary weint (about 5 tirnes as high as in Iinsley Pond) are associated. with a 24 -fold greater total photosynthesis per liter, and it seems unlikely that the difference is entirely an artificial one resulting from 
the difference in methods.

It is interesting to compare the photosynthesis per unit area in Sandusky Eay witb data computed from the literature. On this basis, the average total photosynthesis in sandusky bay was $144 \mathrm{millimoles} \mathrm{O}_{2} / \mathrm{m}^{2} / \mathrm{day}$, which is equivalent to the production of 4 grams of glucose $/ \mathrm{m}^{2} /$ day. Manning and Juday (1941) reported an average total photosynthesis for Weber Lake of 57 millimoles $0_{2} /$ $\mathrm{m}^{2} /$ day. This was the highest of 9 lakes studied. Rabinowitch (1945) quotes an annual averase amounting to 85 millimoles $0_{2} / \mathrm{m}^{2} /$ day for marine phytoplankton. Wright (1954) reported an average pross photosynthetic rate of 28 millimoles $0_{2} / \mathrm{m}^{2} /$ day for Atwood Lake. Riley (1940) obtained rates of 67 milimoles $\mathrm{O}_{2} / \mathrm{m}^{2} /$ day in Iinsley pond. Jackson and rickaden (1954) reported rates amounting to $210 \mathrm{millimoles} \mathrm{O}_{2} / \mathrm{m}^{2} /$ day. The author obtained rates (unpublished) of $150 \mathrm{millimoles} \mathrm{O}_{2} / \mathrm{m}^{2} /$ day in western lake Erie waters in the summer of 1953. These comparisons show that although photosynthesis per liter, the standing crop of phrtoplankton, the ash-free dry weight of suspensoids, the chlorophyll content of water, etc., may vary over several orders of manitude, the photosynthetic rates per unit area within these widely different environments lie within the same order of magnitude. The similarity of correlation coefficients in the 
$\mathrm{O}_{2}$ and $\mathrm{CO}_{2}$ data plotted against ash-fres dry weight and standing crop indicate that the method using $\mathrm{pH}$ change as an index of photosyntbesis is as reliable as the winkler method of following $\mathrm{O}_{2}$ change. These correlation coefficients are notably higher than those obtained by Riley (1940) for $\mathrm{O}_{2}$ production plotted against ash-free dry weight and standing crop which were 0.051 and 0.150 respectively.

Populations may vary in protoplasmic content (Verduin, 1952) and sedgwick-Rafter type counts do not include the bacterial and fungal flora which would be contained in the measurements of ash-free dry weight. Rates per unit ash-free dry weight reported by various authors show less disparity than with rates pertaining to phytoplankton volume. The average maximum results obtained in this study were 2.3 micromoles $\mathrm{O}_{2}$ evolved/hr/mg ash-free dry weight; Jackson and Mcradden (1954) obtained averare rates in Sanctuary Lake of 1.34 micromoles $\mathrm{CO}_{2}$ absorbed $/ \mathrm{hr} / \mathrm{mg}$; and Riley (1940) in Linsley Pond obtained an average surface rate of $0.32 \mathrm{micromoles} \mathrm{O}_{2}$ produced $/ \mathrm{hr} / \mathrm{mg}$ ash-free dry weight of organic matter.

Since different bodies of water present a wide variance in organic seston, it is important that more extensive studies be made to indicate the range of photosynthetic values per unit of ash-free dry weight. This was 
apparent in the study on sandusky Bay where the organic matter varied from 5.8 to $300 \mathrm{mg}$. ash-free dry weight per liter.

The phytoplankton populations in this study represented two rather distinct communities, Cyclotella during February and March, and Melosira in May and June. The photosynthetic rates of these two communities vary by a factor of 1.7. The organisms comprising the separate communities differ in cell volume, protoplasmic content and perhaps physiological activity. They also occurred at different environmental temperatures. It is important that data be obtained pertaining to the metabolic activity of phytoplankton communities rather than being lumped as "standing crop". Such rates may be obtained in relatively short periods of 4 to 6 hours and the methods used in the present study require no more effort than the accepted methods of determinins standing crop. Contributions have been made in this direction by Verduin (1952) and Jackson and Mcradden (1954).

\section{STMMMARY}

A study of the photosynthetic and respiratory activity of the phytoplankt on of Sandusky Bay was made from February 2 to June 18, 1954.

The waters of Sandusky Bay are characterized by high turbidity. The decimal reduction distance averaged $0.36 \mathrm{~m}$. 
The light absorption coeficient averaged 0.12 . The average euphotic zone comprised $70 \%$ of the water column.

Oven-dry suspensoids averaged $121.8 \mathrm{mg}$. per liter and ash-free dry weight of suspensoids averaged $11.78 \mathrm{mg}$. per Iiter. Phytoplankt on population ranged from $0.007 \mathrm{x}$ $10^{10} \mu^{3}$ to $5.73 \times 10^{10} \mu^{3}$ per liter and averaged $1.3 \mathrm{x}$ $10^{10} \mu^{3}$ per liter; diatoms were the predominant component. The average photosynthetic rate in optimal light, based on $\mathrm{CO}_{2}$ consumption per $1010^{3} 3$ was 15 micromoles per hour; the ratio of $\mathrm{CO}_{2}$ consumption to $\mathrm{O}_{2}$ evolution was 1.16.

The total productivity on an area basis was 144 millimoles $\mathrm{O}_{2} / \mathrm{m}^{2} /$ day, or the equivalent of 4 grams of glucose per square meter per day.

pH changes in suriace samples from the Bay during the 6-hour test periods indicated $\mathrm{CO}_{2}$ absorption amounting to $75 \%$ of the avera e total photosjnthesis at optimal light observed in the bottles.

Photosynthetic rates at periols of low levels of phytoplankton population indicate the presence of important quantities of organisms that are not detected by observation under 100x magnification. Chemosynthetic and photosynthetic bacteria may be responsible for this phenomenon. A respiratory quotient of 3.3 was obtained, indicating $\mathrm{CO}_{2}$ evolution considerably in excess of $\mathrm{O}_{2}$ con- 
sumption. This phenomenon also sugests the activity of a bacterial or fungal component causing production of $\mathrm{CO}_{2}$ or some other acid in the dark. More information is needed regarding the bacterial and fungal components or phytoplankton.

The correlation of $\mathrm{CO}_{2}$ consumed per liter with ashfree dry weight of suspensoids was 0.604 ; with phytoplankton volume was 0.388 . The correlation coefficient of $\mathrm{O}_{2}$ evolved per liter with ash-free dry weight of suspensoids was 0.413 ; with phytoplankt on volume it was 0.457 . These coeficients of correlation indicate that phytoplankton volume and ash-free dry weight are of the same order of reliability as indices of productivity in sandusky Pay. Only one of these correlations $\left(\mathrm{CO}_{2}\right.$ consumed with ash-free dry weight of suspensoids) is significant at the 5\% level. These correlations indjcate further, that measurements of photosynthesis by means of pH determinations are as reliable as those based on oxycen determinations using the winklor method. The latter method is considerably more tedious and time-consuming. 


\section{REFERENCES}

Beaver, W. C. 1942. Bacterial Activities in the Subaquatic Soils of Lake Erie. ohio Jour. Sci. 42 (3) : 91-98.

Dye, J. F. 1944. Calculation of alkalinities and free carbon dioxide by the use of nomographs. Jour. Amer. Water Works Ass'n. 36: 895-900.

Henrici, A. T. 1.939. The Distribution of Bacteria in Lakes. Froblems of Lake Biology. p. 39-64 Amer. Ass'n Adv. Sci. The Science Press.

Jacks on, D. F. and J. McFadden. 1954. Phytoplankt on Photosynthesis in Sanctuary Lake, Pymetuning Reservoir. Ecolog 35 (1) : 1-4.

Take Erie Pollution Survey. Supplement. 1953. State of Ohio Department of Natural Reaources. Division of Water.

Ianclois, T. F. 1954. The Western End of Lake Erie and its Foology. Edwards Brothers, Inc., Ann Arbor, Michigan.

Manning, W. M. and R. Juday. 1951. The Chlorophyll Content and Productivity of some Iakes in Northeastern Wisconsin. Wis. Acad. Sci. 33: 363-393.

Moore, E. W. 1939. Graphic Determination of Carbon Dioxide and the Three Forms of Alkalinity. Jour. Amer. Water Works Assin. 31 : 51-56.

Rabinowitch, ت. I. 1945. Fhotosynthesis I. Interscience Publishers, Inc., New York.

Riley, G. A. 1940. Limnolocical Studies in Connecticut. Part IIT. The Plankton of Linsley Pond. Ecol. Moner. 10: 280-306.

Standard Methods for the Txamination of Water and Sewage. 8th Ed. 1936. American Public Fealth Association.

van Nie1, C. B. 1935. Photosynthesis of Bacteria. Cold spring Harbor Symposium on Quantitative Biolosy. 3: 138-150. 
Verduin, J. 1951. Photosynthesis in naturally reared a guatic communities.

plant Physiol. 26: 45-49.

1952. Photosynthesis and growth rates of two diatom communities in Western Lake Erie. Ecology 33 : $163-169$.

1854. Phytoplankton and turbidity. in Western Iake srie.

Ecology 35 (In press).

Weeks, 0. B. 1943. A Survey of the Heterotrophic Bacterial population in the sediment of western Lake Erie.

Doctoral Dissertation. The Ohio State Thiversity.

Welch, P. S. 1848. Iimnological liethods. The Blakj.ston Company., Philadelphia.

Wilson, Ira T. 1938. The Nature, Distribution and Quality of Sediment in the Tpper Part of Sandusky Bay. Mimeographed Manus cript in the Library of Franz Theodore Stone Institute of Iydrobiology.

Wright, J. C. 1954. The Hydrobiology of Atwood Lake, a Flood-control Reservoir. Ecolory 35 (3) : 305-316. 


\section{AUTOBIOGRAPHY}

I, Arthur George incquate, was born in Funtington, Lorain County, ohio, March 31, 1896. I received my secondary education in the public schools of Iitchfield and Medina, Ohio. My undergraduate training was obtained at Denison Tniversity, from which I received the degree Bachelor of Science in 1920. From the Tniversity of Michigan, I received the degree Master of Science in 1948. In 1951 I registered at The obio state University, where I have specialized in the field of Hydrobiology at the Institute of Hydrobiology while completing the requirements for the aerree Doctor of Philosophy. 